\title{
SISTEM INFORMASI GEOGRAFIS (SIG) PERINGATAN DINI BENCANA GEOLOGI BERBASIS MOBILE
}

\author{
Faisal Al Isfahani1; Herman Sugiharto²; Siti Nur Aisah³ ${ }^{3}$ Rohmat Gunawan ${ }^{4}$ \\ ${ }^{124}$ Program Studi Informatika Fakultas Teknik \\ ${ }^{3}$ Program Studi Pendidikan Geografi Fakultas Keguruan dan Ilmu Pendidikan \\ Universitas Siliwangi \\ http://www.unsil.ac.id \\ 1177006047@student.unsil.ac.id,2177006045@student.unsil.ac.id, \\ ${ }^{3}$ sitinuraisah630@gmail.com, ${ }^{4}$ rohmatgunawan@unsil.ac.id
}

\begin{abstract}
Indonesia which is located in the Pacific ring of fire (an area with a lot of tectonic activity) has the potential of high geological natural disasters such as: volcanic eruptions, earthquakes and tsunamis. Submission of information when the disaster occurs from related parties to the community is not optimal. This can cause a high risk of material and non-material losses. The increasing number of smartphone users in Indonesia is one of the potentials to convey disaster-related information. In order to deliver information easily, a system is developed that can be used by relevant parties to convey information to the public. Internet technology, digital maps, smartphones and online databases are used to support the smooth operation of geographic information systems (GIS) developed. The designed solutions are implemented into an information technology-based application. The application developed consists of two platforms. First, web-based applications are designed to manage disaster information that can be accessed by officers from related institutions. Second, mobilebased applications are designed to display disasterrelated information that is accessible to the public. Functional experimental results show that the application prototype developed has been able to produce information: the location of the disaster, display route information to the point of evacuation, and safety guidelines when a disaster occurs.
\end{abstract}

\section{Keywords: Disaster, Geology, GIS, Mobile}

Intisari-Indonesia yang berlokasi di cincin api pasifik (wilayah dengan banyak aktivitas tektonik) memiliki potensi bencana alam geologis yang tinggi seperti: letusan gunung api, gempa bumi dan tsunami. Penyampaian informasi ketika bencana terjadi dari pihak terkait kepada masyarakat belum optimal. Hal ini dapat menimbulkan tingginya resiko kerugian materi dan non-materi. Meningkatnya jumlah pengguna smartphone di Indonesia merupakan salah satu potensi untuk menyampaikan informasi terkait bencana. Agar penyampaian informasi dapat dilakukan dengan mudah, maka dikembangkan suatu sistem yang dapat digunakan oleh pihak terkait untuk menyampaikan informasi kepada masyarakat. Teknologi internet, peta digital, smartphone dan online database digunakan untuk mendukung kelancaran operasional sistem informasi geografis (SIG) yang dikembangkan. Solusi yang dirancang diimplementasikan ke dalam suatu aplikasi berbasis teknologi informasi. Aplikasi yang dikembangkan terdiri dari dua platform. Pertama, aplikasi berbasis web dirancang untuk mengelola informasi bencana yang dapat diakses oleh petugas dari institusi terkait. Kedua, aplikasi berbasis mobile dirancang untuk menampilkan informasi terkait bencana yang dapat diakses oleh masyarakat. Hasil percobaan fungsional menunjukan, prototype aplikasi yang dikembangkan telah dapat menghasilkan informasi: lokasi terjadinya bencana, menampilkan informasi rute menuju titik evakuasi, dan panduan keselamatan ketika terjadi bencana.

Kata Kunci: Bencana, Geologi, Mobile, SIG

\section{PENDAHULUAN}

Berdasarkan Data Informasi Bencana Indonesi - Badan Nasional Penanggulangan Bencana (DIBI)-BNPB, tercatat lebih dari 1.800 kejadian bencana pada periode tahun 2005 hingga 2015. Kecenderungan jumlah kejadian bencana relatif terus meningkat. Bencana geologis, khususnya gempa bumi dan tsunami banyak menimbulkan dampak yang cukup besar (Wilem Rampangilei, B Wisnu Widjaja, 2016).

Keberadaan sistem informasi peringatan dini yang dapat memberikan informasi awal, berdasarkan gejala-gejala alamiah yang muncul berkaitan dengan bahaya bencana merupkan suatu hal penting dilakukan (Iswanto \& Raharja, 2010), (Tedy Setiadi, 2018). Sistem informasi yang dilengkapi dengan tampilan visual pemetaan suatu 
lokasi atau Sistem Informasi Geografis (SIG) merupakan salah satu pendekatan yang dapat dijadikan alternatif solusi untuk masalah ini. SIG memungkinkan dirancang untuk dapat menampilkan koordinat suatu lokasi pada peta digital, rute menuju suatu titik lokasi dan jarak antar titik (Suryadi, Mubarok, \& Gunawan, 2018), (Edy Irwansyah, Tri Buana Saputra, Lim Piu, \& Krisna Wirangga, 2012), (Andretha, Lumban, \& Fibriani, 2017).

Dalam kurun waktu 4 tahun terakhir smartphone di Indonesia berkembang dengan sangat cepat, ditandai dengan masuknya Indonesia ke peringkat 5 pengguna smartphone terbesar di dunia dan pengguna internet nomor 6 di dunia (Yusuf, 2014). Menurut laporan ABC News pada akhir Mei 2013 bahwa pengguna rata-rata mengakses ponselnya 150 kali setiap hari (Gifary, 2015). Meningkatnya jumlah pengguna smartphone di Indonesia merupakan salah satu potensi untuk menyebarkan informasi terkait bencana. Pengembangan aplikasi untuk penangangan bencana berbasis mobile dapat membantu permasalahan manajemen penanganan bencana dan keadaan darurat dengan menghubungkan para pengambil keputusan, dan elemen pendukung(Fitriansyah, Silmi Fauzianti, 2013).

Beberapa solusi terkait penanganan bencana telah dilakukan pada penelian sebelumnya, diantaranya : pemanfaatan sistem informasi geografis dalam penanganan bencana (Edy Irwansyah et al., 2012), (Supriyono, Guntar, Edwar, Zairin, \& Sugandi, 2018). Pengembangan aplikasi berbasis mobile dalam penanganan bencana (Indriasari, Anindito, \& Julianto, 2015), (Khudabadi, 2015), (Bahagia, Satria, \& Ahmadian, 2017).

Dalam penelitian ini diterapkan sistem informasi berbasis visual atau geografis dan aplikasi berbasis mobile dalam solusi peringatan dini terhadap bencana. Aplikasi yang dikembangkan terdiri dari dua platform. Pertama, aplikasi berbasis web dirancang untuk digunakan dalam mengelola informasi bencana yang dapat diakses oleh petugas pusat informasi bencana dari institusi terkait. Kedua, aplikasi berbasis mobile yang dirancang untuk dapat menampilkan informasi lokasi bencana, rute menuju titik evakuasi, dan panduan keselamatan ketika terjadi bencana yang dapat digunakan oleh masyarakat.

\section{BAHAN DAN METODOLOGI}

Terdapat empat tahapan utama yang dilkukan dalam penelitian ini, diantaranya: analisis dan pengumpulan data, perancangan sistem, pembuatan prototype, pengujian dan evaluasi.
Secara umum tahapan yang dilakukan ditampilkan pada gambar 1 .

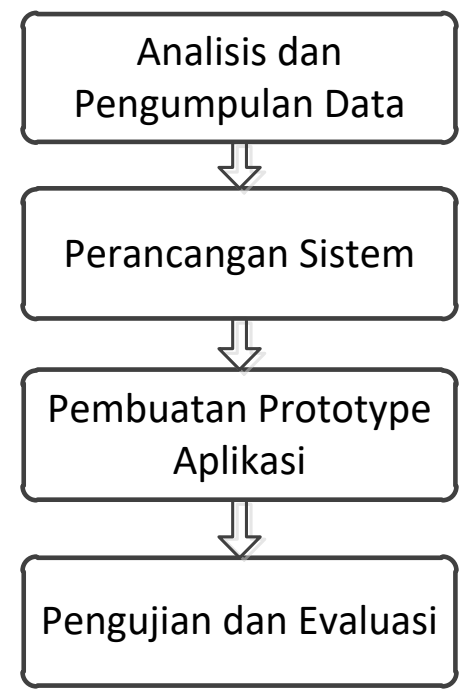

Sumber: (Isfahani, Sugiharto, Aisah, \& Gunawan, 2019)

\section{Gambar 1. Tahapan Penelitian}

Gambar 1 menampilkan tahapan yang dilakukan dalam penelitian ini. Berikut aktivitas yang dilakukan pada setiap tahapan:

\section{Analisis dan Pengumpulan data}

Pada tahap ini dilakukan studi pustaka dari beberapa sumber terkait informasi bencana geologi serta upaya penanggulangannya. Selain dari itu juga dilakukan observasi ke Kantor Pusat Vulkanologi dan Mitigasi Bencana Geologi (PVMBG) Gunung Galunggung Kabupaten Tasikmalaya Jawa Barat dan Kantor Badan Penanggulangan Bencana Daerah (BPBD) Kabupaten Tasikmalaya Jawa Barat.

\section{Perancangan Sistem}

Pada tahap ini dilakukan perancangan sistem untuk solusi yang akan diusulkan berupa aplikasi berbasis teknologi informasi. Rancangan sistem yang dibuat meliputi: perancangan arsitektur sistem, perangan relasi tabel dan perancangan antarmuka aplikasi.

\section{Pembuatan Prototype Aplikasi}

Rancangan sistem yang telah dibuat sebelumnya, pada tahap ini akan diimplementasikan ke dalam suatu aplikasi dengan memanfaatkan teknologi informasi. Implementasi dilakukan dalam bentuk aplikasi berbasis web yang dirancang untuk digunakan oleh petugas dari institusi terkait dan aplikasi berbasis mobile yang dirancang untuk digunakan oleh masyarakat umum.

\section{Pengujian dan Evaluasi}

Pada tahap ini dilakukan pengujian prototypedan evaluasi terhadai aplikasi yang telah dibuat. 


\section{HASIL DAN PEMBAHASAN}

\section{Hasil Analisis Data}

Terdapat beberapa data yang berhububungan dengan gempa. Secara umum data yang berkaitan dengan gempa ditampilkan pada tabel 1.

Tabel 1. Data yang berkaitan dengan gempa

\begin{tabular}{ccl}
\hline No & \multicolumn{1}{c}{ Data } & \multicolumn{1}{c}{ Isi Data } \\
\hline \multirow{2}{1}{$\begin{array}{l}\text { Data } \\
\text { Bencana }\end{array}$} & $\begin{array}{l}\text { Jenis Bencana, Tanggal Kejadian, } \\
\text { Waktu Kejadian, Lokasi Bencana } \\
\text { (Provinsi,Kabupaten), letak } \\
\text { geografi, penyebab bencana, } \\
\text { deskripsi dan kondisi cuaca }\end{array}$ \\
\hline 2 & $\begin{array}{l}\text { Data } \\
\text { Tangap } \\
\text { Bencana }\end{array}$ & $\begin{array}{l}\text { Jenis Bencana, Isi Tanggap bencana, } \\
\text { Illustrasi }\end{array}$ \\
\hline \multirow{3}{3}{3} & $\begin{array}{l}\text { Data } \\
\text { Cuaca }\end{array}$ & $\begin{array}{l}\text { Koordinat, Keadaan Cuaca, Suhu, } \\
\text { Tekanan, Kelembapan, Suhu } \\
\text { Maksimal, Suhu Terendah, Angin, } \\
\text { dan Awan }\end{array}$ \\
\hline
\end{tabular}

Sumber: (Isfahani, Sugiharto, Aisah, \& Gunawan, 2019)

Format data yang ditampilkan pada tabel 1 selanjutnya akan dijadikan acuan untuk perancangan arsitektur data yang diperlukan dalam pengembangan aplikasi.

\section{Perancangan Sistem}

\section{A. Perancangan Arsitektur Sistem}

Aplikasi yang dikembangkan terdiri dari dua platform. Pertama, aplikasi berbasis web yang dirancang untuk digunakan oleh petugas pusat informasi BPBD. Kedua, aplikasi berbasis mobile yang dirancang untuk digunakan oleh masyarakat. Secara umum arsitektur sistem yang dirancang ditampilkan pada gambar 2 .

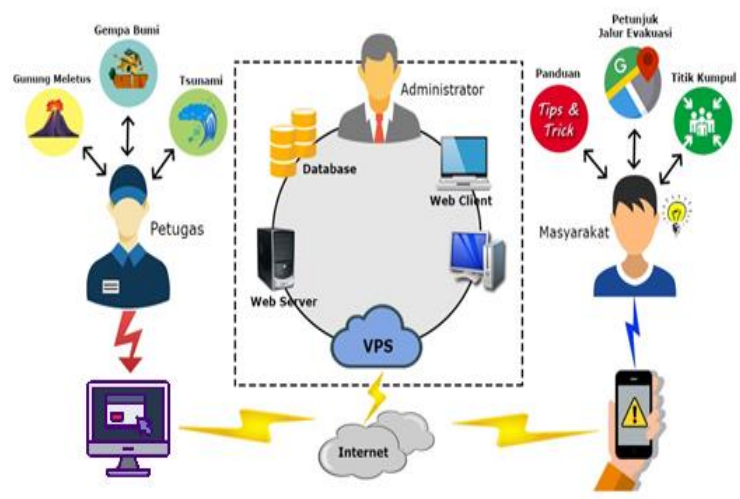

Sumber: (Isfahani, Sugiharto, Aisah, \& Gunawan, 2019)

Gambar 2. Arsitektur Sistem Informasi Geografis (SIG) Peringatan Dini Bencana Geologi
Gambar 2 menampilkan arsitektur sistem yang dikembangkan secara umum. Terdapat 3 bagian utama: aplikasi berbasis web yang dirancangan untuk digunakan oleh petugas BPBD, aplikasi berbasis mobile yang dirancang untuk diakses oleh masyarakat, dan infrastruktur server yang berisi data dan aplikasi. Infrastruktur sistem memerlukan koneksi internet pada tahap implementasinya.

\section{B. Perancangan Arsitektur Data}

Terdapat 12 tabel yang dirancang untuk menyimpan data-data yang berhubungan dengan aplikasi yang dikembangkan. Secara umum realasi antar tabel ditampilkan pada gambar 3 .

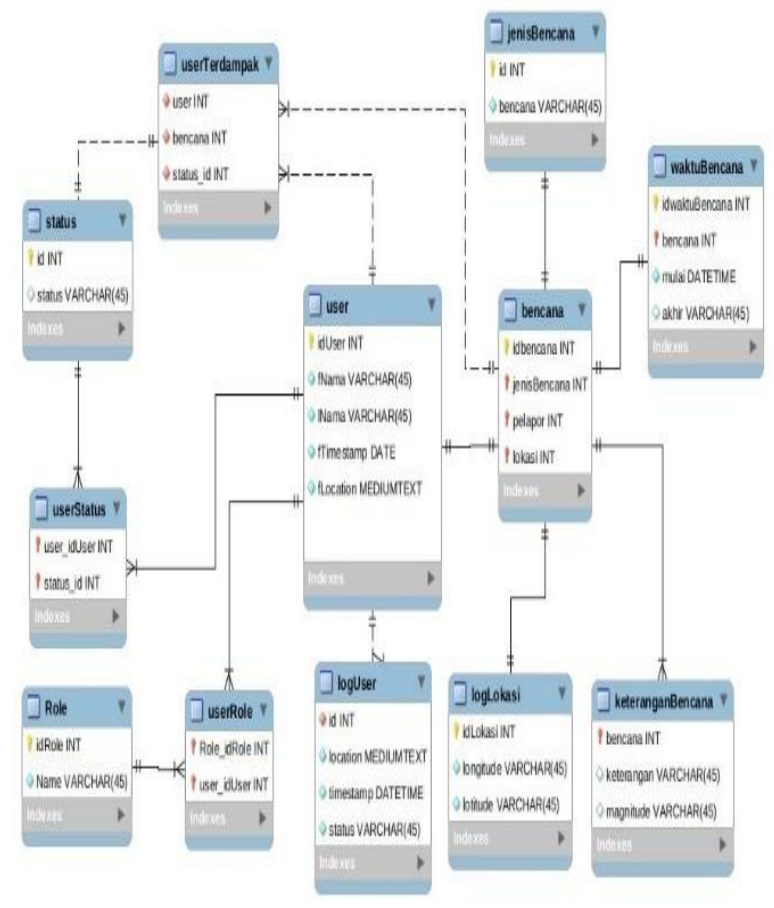

Sumber: (Isfahani, Sugiharto, Aisah, \& Gunawan, 2019)

Gambar 3. Relasi Antar Tabel Aplikasi Peringatan Dini Bencana Geologi

Gambar 3 menampilkan relasi antar tabel yang dirancang untuk digunakan menampung data-data terkait bencana pada aplikasi yang dikembangkan.

\section{Perancangan Antarmuka Aplikasi}

Rangangan antarmuka aplikasi terdiri dari dua bagian utama: antar muka aplikasi berbasis web dan antarmuka aplikasi berbasis mobile. Rancangan antarmuka berbasis web ditampilkan pada gambar 4 . 


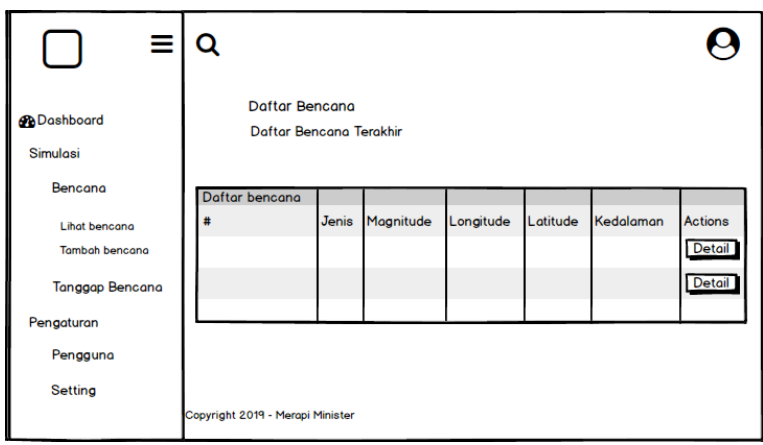

Sumber: (Isfahani, Sugiharto, Aisah, \& Gunawan, 2019)

Gambar 4. Rancangan antarmuka berbasis web

Aplikasi Peringatan Dini Bencana Geologi

Gambar 4 menampilkan rancangan antarmuka dashboard website untuk digunakan petugas BPBD. Terdapat beberapa menu di sebelah kiri, dan konten utama di sebelah kanan. Selain rancangan antarmuka aplikasi berbasis web juga dibuat rancangan muka berbasis mobile.

Terdapat 3 fitur utama pada aplikasi berbasis mobile, diantaranya: informasi lokasi bencana, jalur evakuasi dan tips menghadapi bencana. Rancangan antarmuka tampilan aplikasi berbasis mobile untuk fitur infomasi lokasi bencana ditampilkan pada gambar 5 .

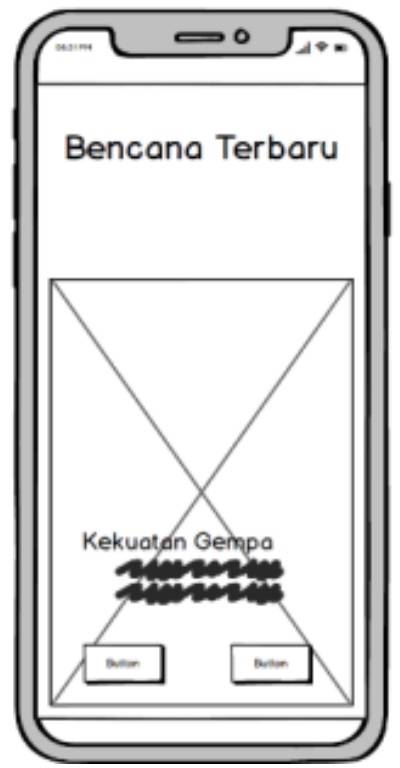

Sumber: (Isfahani, Sugiharto, Aisah, \& Gunawan, 2019)

Gambar 5. Rancangan antarmuka halaman awal informasi bencana

Informasi awal tentang bencana yang terjadi juga dirancang untuk dapat diakses lebih detail. Rancangan antarmuka detail informasi bencana ditampilkan pada gambar 6 .

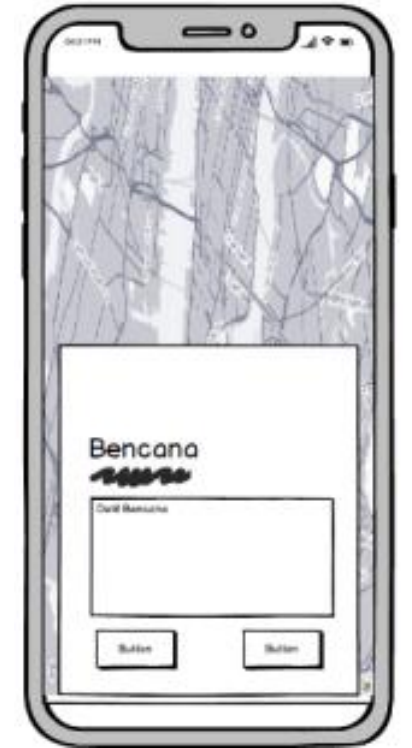

Sumber: (Isfahani, Sugiharto, Aisah, \& Gunawan, 2019)

Gambar 6. Rancangan antarmuka detail informasi bencana

Selain informasi lokasi gempa juga dirancang untuk dapat menampilkan informasi jalur evakuasi menuju titik kumpul. Rancangan antarmuka jalur evakuasi menuju titik kumpul ditampilkan pada gambar 7 .

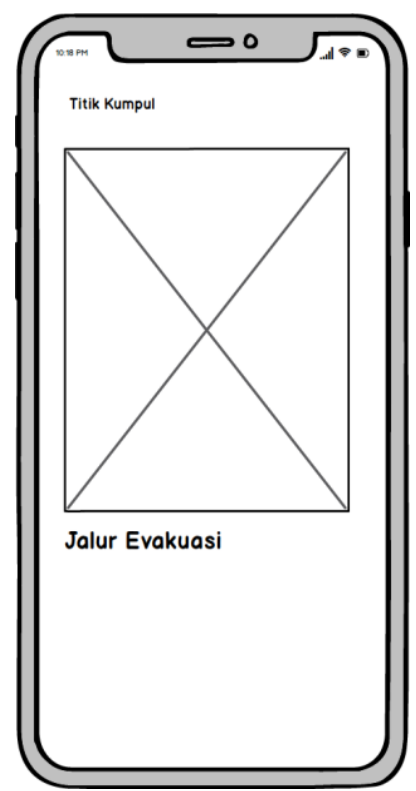

Sumber: (Isfahani, Sugiharto, Aisah, \& Gunawan, 2019)

Gambar 7. Rancangan antarmuka jalur evakuasi

Gambar 7 menampilkan rancangan antar muka jalur evakuasi menuju titik kumpul, meliputi: peta ditigal lokasi gempa, koordinat titik kumpul dan rute menuju titik kumpul. 


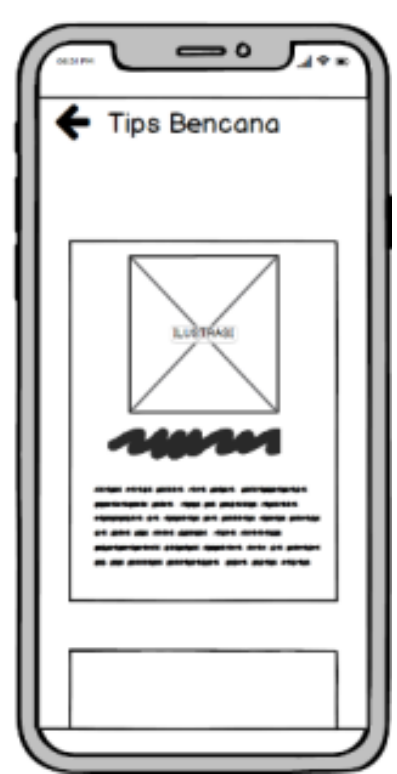

Sumber: (Isfahani, Sugiharto, Aisah, \& Gunawan, 2019)

Gambar 8. Rancangan antarmuka panduan menghadapi bencana

Gambar 8 menunjukan tampilan rancangan antarmuka informasi paduan keselamatan atau tisp menghadapi bencana. Informasi dirangang untuk dapat ditampilkan dalam bentuk gambar yang dilengkapi dengan teks.

\section{Prototype Aplikasi}

Setelah dibuat rancangan, tahap berikutnya implmentasi ke dalam aplikasi berbasis web dan aplikasi berbasi mobile. Hasil implementasi berbasi web ditampilkan pada gambar 9 .

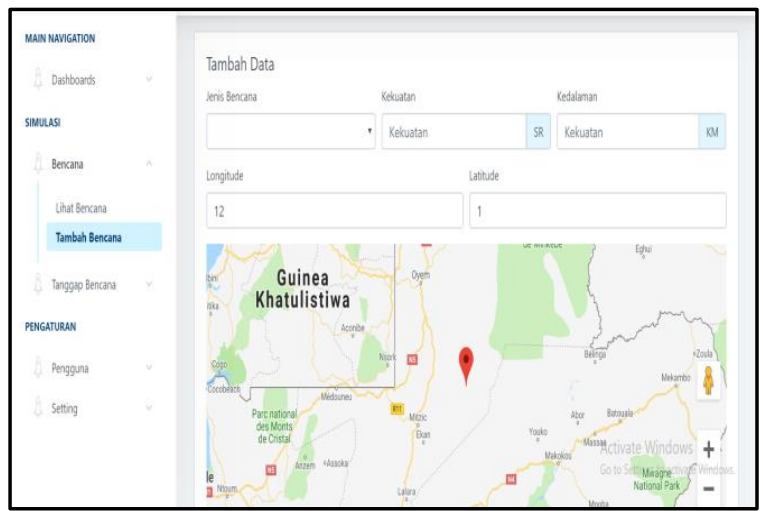

Sumber: (Isfahani, Sugiharto, Aisah, \& Gunawan, 2019)

Gambar 9. Tampilan Aplikasi berbasis web

Gambar 9 menunjukan tampilan aplikasi berbasis web yang dirancang untuk digunakan oleh petugas BPBD dalam mengelola data bencana. Di sebelah kanan terdapat peta digital yang menampilkan koordinat lokasi terjadi gempa.
Informasi data gempa yang diinput oleh petugas dapat diakses melalui aplikasi berbasis mobile yang dirancang untuk diakses oleh masyarakat seperti ditampilkan pada gambar 10 .

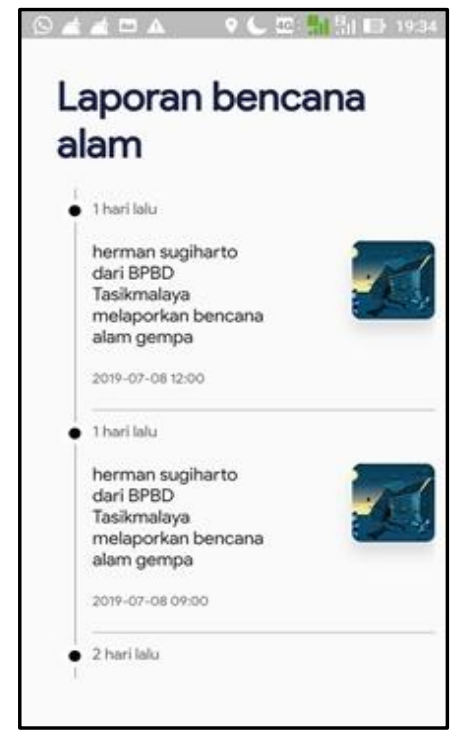

Sumber: (Isfahani, Sugiharto, Aisah, \& Gunawan, 2019)

Gambar 10. Tampilan Aplikasi Mobile Informasi Bencana Terdekat

Gambar 10 manampilkan informasi bencana dari aplikasi aplikasi berbasis mobile. Informasi bencana ditampilkan secara terurut berdasarkan waktu kejadian. Detail informasi bencana dapat diakses dengan cara menyentuh (touch) gambar atau teks. Detail informasi bencana ditampilkan pada gambar 11 .

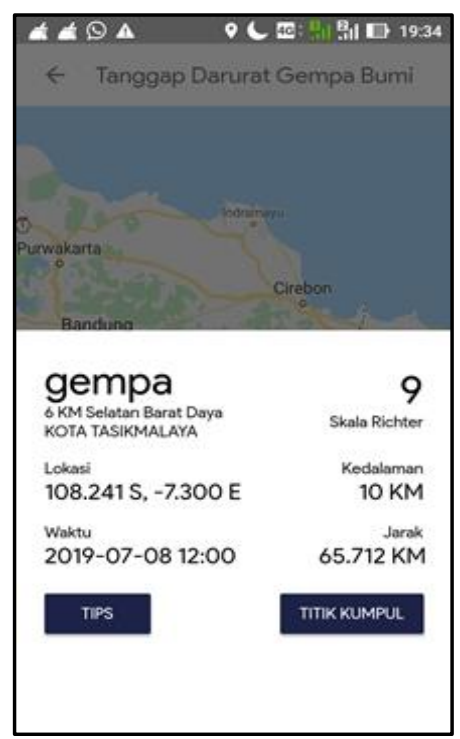

Sumber: (Isfahani, Sugiharto, Aisah, \& Gunawan, 2019)

Gambar 11. Tampilan Aplikasi Mobile Detaial Informasi Bencana 
Gambar 11 merupakan contoh tampilan detail informasi ketika terjadi bencana gempa. Informasi yang ditampilkan berupa: peta digital, lokasi, waktu, kedalaman, besaran gempa (skala richter).

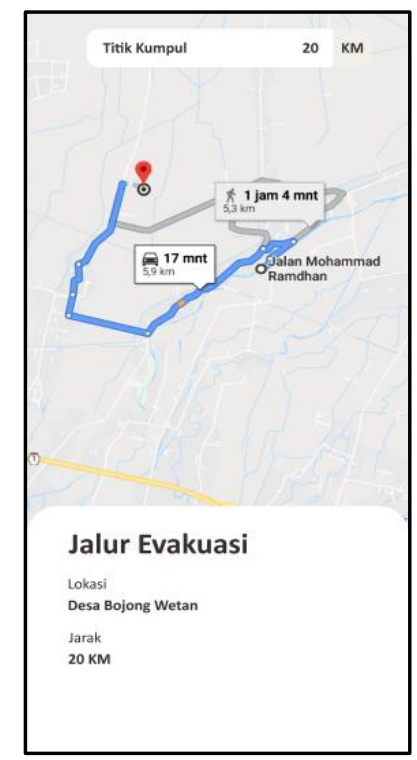

Sumber: (Isfahani, Sugiharto, Aisah, \& Gunawan, 2019)

Gambar 12. Tampilan Aplikasi Mobile Informasi Jalur Evakuasi

Petugas dari institusi terkait dapat menempatkan lokasi titik kumpul pada peta digital yang menjadi acuan untuk dibuat jalur evakuasi seperti ditampilkan pada gambar 12 .

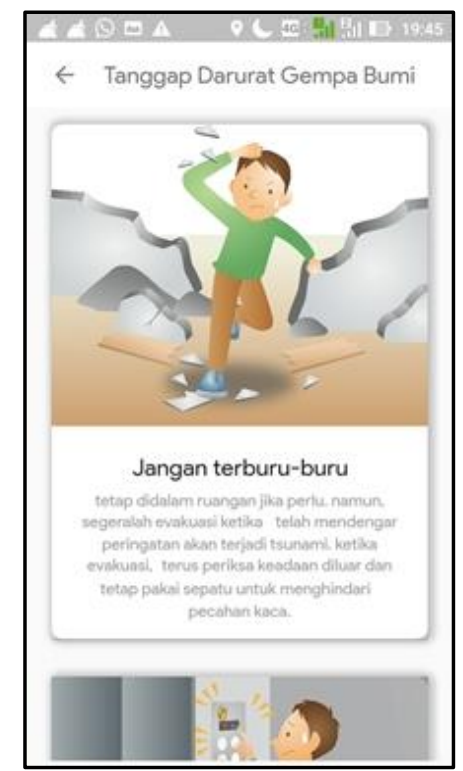

Sumber: (Isfahani, Sugiharto, Aisah, \& Gunawan, 2019)

Gambar 13. Tampilan Aplikasi Mobile Informasi Tips Menghadapi Bencana
Gambar 13 merupakan salah satu contoh informasi paduan keselamatan dalam menghadapi bencana. Informasi disajikan dalam bentuk gambar yang berhubungan dengan jenis bencana dan dilengkapi dengan deskripsi panduan yang dapat dilakukan ketika terjadi bencana.

\section{Pengujian Protoptype}

Pada tahap ini dilakukan pengujian fungsional dari prototype aplikasi yang telah dikembangkan. Tahap pengujian dilakukan pada platform aplikasi berbasis web dan berbasi mobile. Data hasil pengujian fungsional pada aplikasi berbasis web ditampilkan pada tabel 2 .

Tabel 2. Hasil Pengujian Fungsional Aplikasi Berbasis Web

\begin{tabular}{|c|c|c|}
\hline Test case & Hasil yang diharapkan & Status \\
\hline $\begin{array}{l}\text { Lihat } \\
\text { bencana }\end{array}$ & Tampil data bencana & Pass \\
\hline $\begin{array}{l}\text { Detail } \\
\text { bencana }\end{array}$ & Tampil detail bencana & Pass \\
\hline $\begin{array}{l}\text { Tambah data } \\
\text { bencana }\end{array}$ & $\begin{array}{l}\text { - Dapat terpetakan dari } \\
\text { hasil perhitungan } \\
\text { longitude dan latitude } \\
\text { pada tampilan maps } \\
\text { API } \\
\text { - Data yang diinput } \\
\text { dapat diakses pada } \\
\text { menu lihat bencana }\end{array}$ & Pass \\
\hline
\end{tabular}

Sumber: (Isfahani, Sugiharto, Aisah, \& Gunawan, 2019)

Tabel 2 menunjukan, terdapat 3 item test case yang dilakukan: lihat bencana, detail bencanadan tambah data bencana. Hasil pengujian dari ketiga test case tersebut menunjukan bahwa ketiga fungsi tersebut telah sesuai dengan yang diharapkan. Data hasil pengujian fungsional pada aplikasi berbasis mobile ditampilkan pada tabel 3 .

Tabel 3. Hasil Pengujian Fungsional Aplikasi Berbasis Mobile

\begin{tabular}{lll}
\hline Test Case & Hasil yang diharapkan & Status \\
\hline Splash Screen & Menampilkan logo aplikasi & Pass \\
\hline $\begin{array}{l}\text { Bencana } \\
\text { Terdekat }\end{array}$ & $\begin{array}{l}\text { Menampilkan bencana } \\
\text { terdekat dengan pengguna }\end{array}$ & Pass \\
\hline Panduan & $\begin{array}{l}\text { Menampilkan panduan } \\
\text { kebencanaan }\end{array}$ & Pass \\
\hline Titik Kumpul & Menampilkan titik kumpul & Pass \\
\hline Cuaca & $\begin{array}{l}\text { Menampilkan data cuaca } \\
\text { terkini }\end{array}$ & Pass \\
\hline Detail Bencana & $\begin{array}{l}\text { Menampilkan titik } \\
\text { bencana di peta }\end{array}$ & Pass \\
& $\begin{array}{l}\text { - Menampilkan data } \\
\text { bencana } \\
\text { - Menampilkan jarak } \\
\text { bencana dengan } \\
\text { pengguna }\end{array}$ & \\
& Sugharto Aisah \& Gunawan, 2019)
\end{tabular}

Sumber: (Isfahani, Sugiharto, Aisah, \& Gunawan, 2019) 
Tabel 3 menunjukan, terdapat 6 item test case yang dilakukan: Splash Screen, Bencana Terdekat, Panduan, Titik Kumpul, Cuaca, Detail Bencana. Hasil pengujian dari setiap test case tersebut menunjukan bahwa fungsional dari setiap item telah sesuai dengan yang diharapkan.

\section{KESIMPULAN}

Percobaan pada penelitian ini telah berhasis mengembangkan sistem informasi geografis (SIG) peringatan dini bencana geologi yang diimplementasikan ke dalam prototype aplikasi. Prototype aplikasi yang dikembangkan terdiri dari dua platform. Pertama, aplikasi berbasis web dirancang untuk mengelola informasi bencana yang dapat diakses oleh petugas dari institusi terkait. Kedua, aplikasi berbasis mobile dirancang untuk menampilkan informasi terkait bencana yang dapat diakses oleh masyarakat. Hasil percobaan fungsional menunjukan, prototype aplikasi yang dikembangkan telah dapat menghasilkan informasi: lokasi terjadinya bencana, menampilkan informasi rute menuju titik evakuasi, dan panduan keselamatan ketika terjadi bencana.

\section{UCAPAN TERIMA KASIH}

Terima kasih kepada Direktorat Jenderal Pembelajaran dan Kemahasiswaan (Belmawa) Kementrian Riset, Teknologi dan Pendidikan Tinggi yang telah mendanai penelitian ini melalui pelaksanaan Program Kreativitas Mahasiswa (PKM) Tahun 2019, BPBD Kabupaten Tasikmalaya, Program Studi Informatika Universitas Siliwangi, serta seluruh pihak yang telah berkontribusi dalam penelitian ini.

\section{REFERENSI}

Andretha, J., Lumban, J., \& Fibriani, C. (2017). Pemanfaatan Sistem Informasi Geografis Dan Metode Simple Additive Weighting ( Studi Kasus: Kota Surakarta ). Jurnal Teknologi Informasi Dan Ilmu Komputer (JTIIK), 4(2), 127-135.

Bahagia, Satria, D., \& Ahmadian, H. (2017). Perancangan SIstem Informasi Manajemen Data Korban Bencana Berbasis Mobile Android. Jurnal Manajemen Dan Akuntansi, 3(2), 22-30.

Edy Irwansyah, Tri Buana Saputra, Lim Piu, \& Krisna Wirangga. (2012). Pengembangan
Aplikasi Sistem Informasi Geografis Untuk Monitoring Gempabumi. Jurnal Informatika, 11, 49-54. https://doi.org/10.9744/informatika.11.1.49 $-54$

Fitriansyah, Silmi Fauzianti, T. B. A. (2013). Aplikasi Mobile Penanganan Bencana Dan Keadaan Darurat Berbasis Prosedur Dan Objek Pendukung. Data Manajemen Dan Teknologi Informasi (DASI), 14(1), 23.

Gifary, S. (2015). Intensitas Penggunaan Smartphone Terhadap Perilaku Kompunikasi. Jurnal Sosioteknologi, 14(2), 170-178.

Indriasari, T. D., Anindito, K., \& Julianto, E. (2015). Analisis dan Perancangan Sistem Pengumpulan Data Bencana Alam. Jurnal Buana Informatika, 6(1), 73-82. https://doi.org/10.24002/jbi.v6i1.396

Isfahani, F. Al, Sugiharto, H., Aisah, S. N., \& Gunawan, R. (2019). Laporan Akhir Penelitian Mandiri. Tasikmalaya.

Iswanto, \& Raharja, N. M. (2010). Sistem monitoring dan peringatan dini tanah longsor. Simposium Nasional RAPI IX 2010, 54-62.

Khudabadi, R. (2015). A Recent Study on Early Disaster Warning \& Evacuation System on Mobile Phones Using Google Cloud, 02, 501503.

Supriyono, S., Guntar, D., Edwar, E., Zairin, Z., \& Sugandi, W. (2018). Sosialisasi Potensi Bencana dan Sistem Informasi Geografi (SIG) Kebencanaan di Kabupaten Seluma. Jurnal Bagimu Negeri, 2(1), 59-68. https://doi.org/10.26638/jbn.552.8651

Suryadi, A. A., Mubarok, H., \& Gunawan, R. (2018). Implementasi Sistem Informasi Geografis (Sig) Pada Penyebaran Lokasi Kuliah Kerja Nyata (Kkn). Simetris: Jurnal Teknik Mesin, Elektro Dan Ilmu Komputer, 9(1), 219-224. https://doi.org/10.24176/simet.v9i1.2082

Tedy Setiadi. (2018). Perancangan Sistem Informasi Geografis Pemetaan Daerah Rawan Tanah Longsor ,. Jurnal Algoritma, 7(1), 1-54.

Wilem Rampangilei, B Wisnu Widjaja, L. K. (2016). Risiko bencana indonesia. (M. R. A. Raditya Jati, Ed.). BNPB. 
Yusuf, O. (2014). Pengguna Internet Indonesia Nomor Enam Dunia. 